\title{
Professional Values in Nursing and the Factors Which Affect Them: A Specific Example of a Private Hospital
}

\author{
Tuğba Mert', Serpil Çelik Durmuş \\ 'TOBB ETÜ Hospital, Ankara, Turkey \\ ${ }^{2}$ Nursing Department, Faculty of Health Sciences, Kırıkkale University, Kırıkkale, Turkey
}

*Corresponding Author: Serpil Çelik Durmuş, Ph.D., RN, Assistant Professor, Nursing Department, Faculty of Health Sciences, Kırıkkale University, Kırıkkale, Turkey. Tel: +90-05309334650, Email: serpilcelik2010@gmail.com

Received March 12, 2019; Accepted August 17, 2019; Online Published August 31, 2019

\begin{abstract}
Background: A professional is an individual who prefers a profession, is specially qualified in its technical aspects, and makes a living with the profession.

Objective: This research was conducted to determine the professional values of nurses and the factors affecting them. Methods: This descriptive research evaluated a sample of 97 nurses working in a private hospital in Ankara, Turkey. Data was collected using the demographic form and professional values scale (PVS).

Results: Among the nurses in the study sample, $43 \%$ had a graduate degree, $84.5 \%$ were staff nurses, and $37.2 \%$ were surgery, obstetrics, and cardiovascular surgery nurses. The mean score of professional values of nurses in this study was determined to be $4.20 \pm 0.55$. It was determined that professional values of nurses in the 34 -year and older group, including male nurses, those usually working the day shift, those who chose the profession, those with memberships in associations, and those who participated in scientific meetings/seminars, had higher scores for professional values, but this finding was statistically insignificant $(P>0.05)$.

Conclusion: The professional values of nurses was found to be above the middle level. In this light, it can be recommended, especially to managers, that training on professional values should be planned for nurses. It is also recommended that nurses receive undergraduate education and other comprehensive studies. In order to achieved a desired position in nursing, nurses must update regularly their scientific knowledge, participate in scientific meetings/seminars, and become members of professional associations.
\end{abstract}

Keywords: Nursing, Private Hospital, Professional Values

\section{Background}

Nurses are the initial sources of manual work in hospitals which offer treatment and nursing. ${ }^{1}$ More importantly, nursing is a discipline which involves the health status of and caring for an individual, the family, and the community while improving itself with social, cultural, and technological reforms from the past until the present. ${ }^{2}$ Nursing is defined by the International Council of Nursing (ICN) as a profession which helps public health and targets families and individuals for protection from disorders in a community. It is responsible for treatment and rehabilitation. ${ }^{3}$ Moreover, a "professional" is an individual who prefers a profession, is specially qualified in its technical aspects, and makes a living with it. Also, it is the person who proves his or her qualifications in the field by improving and updating the profession while giving tmost importance to the very close environment and the professional relationships in the field. ${ }^{4}$ Proficiency in the field is a vital criterion for being able to form a high quality process of nursing and caregiving. Any adverse effect on the profession unfavorably effects the nurse first, causing troubles and significant loss of quality in the profession. ${ }^{5}$ Nurses, the key elements of nursing and healthcare services, should have some ethical and professional quality criteria. ${ }^{6}$ These ethical and professional values are the ideals and beliefs to which the nurses are devoted. ${ }^{7}$ They reflect the responsibilities of the nurse, affect his/her emotions, and direct his/her behavior. The ideals and values which are gained by the professional improve the standards of the profession. The quality of nursing and caregiving is a mirror of the ethical and professional values, beliefs, and criteria of all other nurses and personnel in the field. ${ }^{8}$ Moreover, professional values are sources of applications in the field. These values form an important guide with which to improve relationships between individuals and the community. Determining the level of professional

Copyright (C) 2019 The Author(s). This is an open-access article distributed under the terms of the Creative Commons Attribution License (http:// creativecommons.org/licenses/by/4.0), which permits unrestricted use, distribution, and reproduction in any medium, provided the original work is properly cited. 
quality is essential for the progress and improvement of the profession, while it also motivates and directs the performance of high quality future activities and projects in the field..$^{8-10}$ Nurses need support when they are faced with "decision making," "defending their behaviors," and "individual contradictions." They can derive this support from some of their ethical and professional values. ${ }^{11}$ The Association of American Nurses (ANA) and the ICN point out that the wellness of the patient is a crucial must, an important criterion and requirement, while it accepts caregiving as the first priority in the field. The basic values of the profession are autonomy, equality, the honor of the individual, justice, and faithfulness. ${ }^{12,13}$

In order to be qualified, it is necessary for nurses to participate in professional training programs to be qualified. Identifying professional values and those factors that affect such values is another important parameter. The limited number of studies about nursing and the factors affecting its quality prompted the current study, aimed at determining professional values and those values affecting the nursing profession that may improve the working conditions of nurses as well as the quality of care. The professional values of nurses have always been an important guide in the relationships between nurse and patient, nurse and community, and patient and community, and directing decision-making in a healthy manner is part of the basic structure of the profession. It has been copiously reported in the literature that age, gender, profession, educational status, career, qualifications, and professional position strongly affect the professional values of nurse. ${ }^{14-17}$

\section{Objective}

The current study was performed to identify factors affecting the professional values of a nurse during the process of nursing.

\section{Methods}

\subsection{Setting and Samples}

The current study was carried out in a private hospital in Ankara, Turkey. The study population comprised 97 nurses employed at the hospital working 9-hour shifts (hours: 07$16,15-24,23-08)$ who agreed to participate in the study. Data was collected between 15-30 May 2016.

Data was collected using an information form and the professional values scale (PVS). The first four questions in the form asked age, gender, marital status, educational status, and socio-demographic attributes, while questions 5-13 refer to the professional preferences, employment in the hospital, total employment history, the department of employment, shift worked, membership in professional councils, and the frequency of participation in national and international seminars and training programs of the participating nurses. The PVS was first improved and modified by Weis and Schank ${ }^{10}$ and translated into Turkish and tested by Orak and Alpar. ${ }^{18}$ This scale, completed by the participating nurses, consisted of groups containing 31 items scored on a 5-point Likert scale. Each item was scored as 5 - significantly important, 4 - very important, 3 - important, 2 - moderately important, or 1 - not important. Each category was scored as well, and the lowest and highest points were 31 and 155, respectively. Higher scores indicated greater improvement in the level of professionalism. The efficient which was improved and modified by the PVS Weis and Schank is 0.92; whereas it was determined to be the same (0.95) by Orak and Alpar.

\subsection{Data Analysis}

Data was analyzed using the SPSS 18 statistical software program. Descriptive statistics included number, percentage of distribution, and ANOVA tests. The collected data was evaluated at a $95 \%$ confidence interval with $P<0.05$ indicating statistical significance.

\section{Results}

According to the research results, $32 \%$ of THA nurses were in the $26-33$ years age group and $30 \%$ of the nurses were in the 18-25 years age group. Women comprised $92.8 \%$ of participants, $51.5 \%$ were married, $43 \%$ had a graduate degree, $84.5 \%$ were staff nurses, and $37.2 \%$ were surgery, obstetrics and CVS nurses (Table 1).

The average PVS point was determined to be high

Table 1. Distribution of Nurses by Demographic and Socio-Cultural Characteristics

\begin{tabular}{|c|c|c|c|}
\hline Variables & & No. & $\%$ \\
\hline \multirow{5}{*}{ Age } & $18-25$ & 29 & 30 \\
\hline & $26-33$ & 31 & 32 \\
\hline & $34-41$ & 20 & 21 \\
\hline & $42+$ & 17 & 17 \\
\hline & Total & 97 & 100 \\
\hline \multirow{3}{*}{ Gender } & Female & 90 & 92.8 \\
\hline & Male & 7 & 7.2 \\
\hline & Total & 97 & 100 \\
\hline \multirow{3}{*}{ Civil Status } & Married & 47 & 48.5 \\
\hline & Single & 50 & 51.5 \\
\hline & Total & 97 & 100 \\
\hline \multirow{3}{*}{ Education Level } & Health high school & 47 & 48.5 \\
\hline & Bachelor's & 50 & 51.5 \\
\hline & Total & 97 & 100 \\
\hline \multirow{3}{*}{ Position } & Staff Nurse & 82 & 84.5 \\
\hline & Charge Nurse & 15 & 15.5 \\
\hline & Total & 97 & 100 \\
\hline \multirow{5}{*}{ Working Period } & 0-1 year & 20 & 20.6 \\
\hline & 2-5 year & 42 & 43.3 \\
\hline & 6-10 year & 20 & 20,6 \\
\hline & $11-15$ year & 15 & 15.5 \\
\hline & Total & 97 & 100 \\
\hline \multirow{3}{*}{ Working Method } & Day & 31 & 32 \\
\hline & Day- Night & 66 & 68 \\
\hline & Total & 97 & 100 \\
\hline
\end{tabular}


(4.20 \pm 0.55$)(130.44 \pm 16.09)$, and the decision-making status of nurses was independently higher $(4.23 \pm 0.03)$ at the sub-autonomy level. The highest number of points in the sub-levels of PVS was given to the "responsibility" sublevel (Table 2).

Gender, when considering the "honor" sublevel, was found to be significantly important $(P<0.05)$, with men having a higher score than women. The sublevel "action in a severe stage of disease/disorder" was found to have a significant difference $(P<0.05)$, with the higher number of points belonging to single nurses. The "level of education" sub-autonomy level showed a significant difference between groups $(P<0.05)$, and the points belonging to nurses with a Master's or Ph.D. degree were higher. The points for the sub-autonomy levels "independent preference of the profession," membership in a foundation, or council", and participation in training programs, seminars, or congresses were found to be significantly high $(P<0.05)$ (Table 3$)$.

\section{Discussion}

It is necessary for nurses to improve their thinking and decision independently and to have their professional values improved. ${ }^{8}$ Therefore, it is vital that factors affecting professional values be identified and deficiencies in training programs be eliminated. The profession lies within the formation and presentation of professional values. Thus, it is necessary to determine the professional level of the healthcare personnel in the nursing field. The professional values of the nurses in the study sample were determined to be $(130.44 \pm 16.09)$. In the study of Karamanoğlu et al, the professional level of nurses who like their profession and are devoted to their profession were found to be higher. ${ }^{19}$ Studies on related subjects in the literature used data taken from students in the faculties of Nursing and Healthcare. The average score of professional values in the study by Geçkil et al was determined to be $106.45 \pm 13.61$, which was obtained from students and 57 nurses. ${ }^{20}$ Similarly, the score for the same criterion was determined to be $100 \pm 15.61$ in the study by Lin and Wong. ${ }^{21}$ The average score of the professional values of the students was found to be $101.43 \pm 12.78$ in a study by Iacobucci et al. ${ }^{22}$ The current study found scores to be higher than those previously reported. The main reason may be the higher ratio of nurses with $\mathrm{PhD} /$ Master's degrees and higher positions in the field.

Nursing students were found to have the highest scores for professional values in the study by Kaya et al. ${ }^{23}$ In a similar study, the same values given by the students were scored as $182.35 \pm 21.24$, and the values were the same as those in the study by Alfred et al, which were higher than the average, while there was no relation among age, gender, shift, and the other parameters. ${ }^{24}$ On the other hand, the findings of a study by Alfred et al indicated the statistically important significance of the parameters of department, marital status, career degree, and education
Table 2. Nurses' Professionalism Scale Subscale Scores

\begin{tabular}{lcc}
\hline Scale Sub-Dimensions & Mean \pm SD & Median (Min-Max) \\
\hline Human Dignity & $4.29 \pm 0.73$ & $4.36(2.55-5.00)$ \\
Responsibility & $4.39 \pm 0.81$ & $4.00(2.71-5.00)$ \\
Take Action & $4.02 \pm 0.82$ & $4.00(2.60-5.00)$ \\
Autonomy & $4.23 \pm 0.03$ & $4.25(2.25-5.00)$ \\
Security & $4.38 \pm 0.49$ & $4.50(2.50-5.00)$ \\
Total & $4.20 \pm 0.55$ & $4.23(2.58-5.00)$ \\
\hline
\end{tabular}

level. Those factors affecting the profession that were reported in the literature were position, education level, clinical environment, foundation, frequency of shift, and preference for a change in profession. ${ }^{24}$

\section{Conclusion}

Most of the nurses who participated in the current study had participated in seminars, activities, and training programs, but they had no memberships in any council or foundation. It is crucial that the present quality of nurses be improved by becoming qualified and trained in nursing, participating in professional training programs and seminars, and being members of a council or foundation. Nurses should be supported, and it is essential that professional training program be organized $s$ to improve the skills and experience of nurses. Finally, further studies with a higher capacity and more data are urgently needed to determine the professional level of nurses.

\section{Authors' Contributions}

Study design: TM and SÇD; Data collection: TM; Data analysis: TM and SÇD; Study supervision: TM and SÇD; Manuscript writing: TM and SÇD; Critical revisions for important intellectual content: TM and SÇD.

\section{Conflict of Interest Disclosures}

The authors declare no potential conflicts of interest with respect to the research, authorship, and/or publication of this article.

\section{Research Highlights}

\section{What Is Already Known?}

Professional values directly affect the quality of nursing care. The basic values of the profession are autonomy, equality, the honor of the individual, justice, and faithfulness.

\section{What This Study Adds?}

It was determined that nurses have moderate professional values. It can also be explained that the way of working, membership in associations, and participation in seminars or symposiums affect professional values, but statistically insignificantly. 
Mert and Durmuş

Table 3. Demographic and Sociocultural Distribution of Nurses According to their Sub-Dimensions

\begin{tabular}{|c|c|c|c|c|c|c|c|c|c|c|c|c|c|c|c|c|c|c|c|}
\hline \multirow[b]{2}{*}{ Variable } & \multirow{2}{*}{$\mathbf{n}$} & \multicolumn{18}{|c|}{ Scale Sub-dimensions } \\
\hline & & $\begin{array}{l}\text { Human } \\
\text { dignity }\end{array}$ & $P$ & $\mathrm{~F}^{*}$ & Responsibility & $P$ & $\mathrm{~F}$ & $\begin{array}{l}\text { Taking } \\
\text { action }\end{array}$ & $P$ & $\mathrm{~F}$ & Safety & $P$ & $\mathrm{~F}$ & Autonomy & $\boldsymbol{P}$ & $\mathrm{F}$ & Total & $P$ & $\mathrm{~F}$ \\
\hline \multicolumn{20}{|l|}{ Gender } \\
\hline $\begin{array}{l}\text { Female } \\
\text { Male }\end{array}$ & $\begin{array}{l}90 \\
7\end{array}$ & $\begin{array}{l}4.28 \\
4.35\end{array}$ & 0.784 & 0.075 & $\begin{array}{l}4.08 \\
4.24\end{array}$ & 0.479 & 0.480 & $\begin{array}{l}4.02 \\
4.05\end{array}$ & 0.052 & 0.881 & $\begin{array}{l}4.22 \\
4.32\end{array}$ & 0.156 & 0.694 & $\begin{array}{l}4.39 \\
4.25\end{array}$ & 0.404 & 0.526 & $\begin{array}{l}4.2 \\
4.26\end{array}$ & 0.084 & 0.773 \\
\hline \multicolumn{20}{|l|}{ Civil status } \\
\hline \multicolumn{20}{|l|}{ Education } \\
\hline $\begin{array}{l}\text { Associate degree } \\
\text { Undergraduate }\end{array}$ & $\begin{array}{l}47 \\
50\end{array}$ & $\begin{array}{l}4.25 \\
4.32\end{array}$ & 0.579 & 0.310 & $\begin{array}{l}4.03 \\
4.15\end{array}$ & 0.308 & 1.050 & $\begin{array}{l}3.92 \\
4.12\end{array}$ & 0.102 & 2.722 & $\begin{array}{l}4.20 \\
4.25\end{array}$ & 0.707 & 0.142 & $\begin{array}{l}4.31 \\
4.44\end{array}$ & 0.017 & 1.305 & $\begin{array}{l}4.15 \\
4.25\end{array}$ & 0.317 & 1.014 \\
\hline Loyalty to Professio & & & & & & & & & & & & & & & & & & & \\
\hline $\begin{array}{l}\text { Yes } \\
\text { No }\end{array}$ & $\begin{array}{l}77 \\
20\end{array}$ & $\begin{array}{l}4.30 \\
4.28\end{array}$ & 0.055 & 0.904 & $\begin{array}{l}4.11 \\
4.05\end{array}$ & 0.171 & 0.680 & $\begin{array}{l}4.04 \\
3.98\end{array}$ & 0.206 & 0.651 & $\begin{array}{l}4.24 \\
4.23\end{array}$ & 0.054 & 0.970 & $\begin{array}{l}4.43 \\
4.22\end{array}$ & 0.148 & 2.126 & $\begin{array}{l}4.22 \\
4.16\end{array}$ & 0.651 & 0.206 \\
\hline Membership in any & izatio & & & & & & & & & & & & & & & & & & \\
\hline $\begin{array}{l}\text { Yes } \\
\text { No }\end{array}$ & $\begin{array}{l}36 \\
61\end{array}$ & $\begin{array}{l}4.31 \\
4.24\end{array}$ & 0.610 & 0.262 & $\begin{array}{l}4.10 \\
4.09\end{array}$ & 0.909 & 0.053 & $\begin{array}{l}4.03 \\
4.04\end{array}$ & 0.989 & 0.132 & $\begin{array}{l}4.20 \\
4.36\end{array}$ & 0.299 & 1.090 & $\begin{array}{l}4.43 \\
4.26\end{array}$ & 0.181 & 1.819 & $\begin{array}{l}4.22 \\
4.19\end{array}$ & 0.795 & 0.068 \\
\hline Participation in sem & & & & & & & & & & & & & & & & & & & \\
\hline Yes & $\begin{array}{l}74 \\
23\end{array}$ & $\begin{array}{l}4.27 \\
4.32\end{array}$ & 0.682 & 0.501 & $\begin{array}{l}4.09 \\
4.14\end{array}$ & 0.709 & 0.462 & $\begin{array}{l}4.05 \\
4.03\end{array}$ & 0.977 & 0.068 & $\begin{array}{l}4.20 \\
4.28\end{array}$ & 0.195 & 1.600 & $\begin{array}{l}4.45 \\
4.36\end{array}$ & 0.724 & 0.441 & $\begin{array}{l}4.21 \\
4.23\end{array}$ & 0.838 & 0.283 \\
\hline
\end{tabular}




\section{Ethical Approval}

Written permission for this study was obtained from the Chief Physician and Director of Nursing Services of the hospital. At the time of the study, the ethics committee saw enough siganature of the hospital chief physician and director of nursing services. The Turkish Professional Value Scale (TPVS) was validated by Weis and Schank and then adapted into Turkish by Orak and Alpar. Written permission from Orak and Alpar was obtained by email.

\section{References}

1. Akça Ay F. Mesleki temel kavramlar. In: Akça Ay F, ed. Temel hemşirelik kavramlar, ilkeler, uygulamalar. Istanbul: Istanbul Medikal Yayıncılık; 2010: 47. [Turkish].

2. International Counsel of Nursing website. http://www.icn.ch.

3. Öz F. Sağlık alanında temel kavramlar. 2nd Ed. Ankara: Mattek Matbaacılık Basım ve Yayıncılık; 2010:38. [Turkish].

4. Taylan S, Alan S, Kadıoğlu S. Hemşirelik rolleri ve özerklik. Hemşirelikte Araştırma Geliştirme Dergisi. 2012;14(3):66-74. [Turkish]

5. Karadağ G, Uçan Ö. Hemşirelik eğitimi ve kalite. Fırat Sağlık Hizmetleri Dergisi. 2006;1:42-51. [Turkish].

6. Kacaroğlu Vicdan A. Hemşirelikte profesyonellik. Maltepe Üniversitesi Hemşirelik Bilim ve Sanatı Dergisi, Sempozyum Özel Sayısı. 2010;261-263. [Turkish].

7. Adıgüzel O, Tanrıverdi H, Sönmez Özkan D. Mesleki profesyonellik ve bir meslek mensupları olarak hemşireler örneği. Yönet Bilim Derg. 2011;9(2): 235-260.

8. Sabancıoğulları S, Doğan S. Profesyonel kimlik gelişimi ve hemşirelik. Anadolu Hemşirelik ve Sağlık Bilimleri Dergisi. 2012;15(4):275-282. [Turkish].

9. Vezeau TM. Teaching professional values in a BSN program. Int J Nurs Educ Scholarsh. 2006;3:Article25. doi:10.2202/1548$923 \times .1271$.

10. Weis D, Schank MJ. Professional values: key to professional development. J Prof Nurs. 2002;18(5):271-275. doi:10.1053/ jpnu.2002.129224.

11. Pehlivan I. Mesleki Etik. Yönetsel, mesleki ve örgütsel etik. Ankara: Pegem; 2002:84-87. [Turkish].

12. Atalay $\mathrm{M}, \mathrm{Tel} \mathrm{H}$. Gelecek yüzyılda hemşirelikte lisans eğitiminin vizyonu. Cumhuriyet Üniversitesi Hemşirelik Yüksekokulu
Dergisi. 1999;3(2):47-54. [Turkish]

13. Shaw HK, Degazon C. Integrating the core professional values of nursing: a profession, not just a career. J Cult Divers. 2008;15(1):44-50.

14. Rassin M. Nurses' professional and personal values. Nurs Ethics. 2008;15(5):614-630. doi:10.1177/0969733008092870.

15. Sellman D. Professional values and nursing. Med Health Care Philos. 2011;14(2):203-208. doi:10.1007/s11019-010-9295-7.

16. McNeese-Smith DK, Crook M. Nursing values and a changing nurse workforce: values, age, and job stages. J Nurs Adm. 2003;33(5):260-270. doi:10.1097/00005110-20030500000002.

17. Fisher M. A comparison of professional value development among pre-licensure nursing students in associate degree, diploma, and bachelor of science in nursing programs. Nurs Educ Perspect. 2014;35(1):37-42. doi:10.5480/11-729.1.

18. Orak N, Alpar Ş. Hemşirelerin profesyonel değerleri ölçeği'nin geçerlik ve güvenirlik çalışması. Marmara Üniversitesi Sağlık Bilimleri Enstitüsü Dergisi. 2012;2(Suppl 1):S22-S31. [Turkish].

19. Karamanoğlu A, Özer F, Tuğcu A. Denizli ilindeki hastanelerin cerrahi kliniklerinde çalışan hemşirelerin mesleki profesyonelliklerinin değerlendirilmesi. Fırat Tıp Dergisi. 2009;14(1):12-17

20. Geçkil E, Ege E, Akin B, Göz F. Turkish version of the revised nursing professional values scale: validity and reliability assessment. Jpn J Nurs Sci. 2012;9(2):195-200. doi:10.1111/ j.1742-7924.2011.00202.x

21. Lin YH, Wang LS. A Chinese version of the revised Nurses Professional Values Scale: reliability and validity assessment. Nurse Educ Today. 2010;30(6):492-498. doi:10.1016/j. nedt.2009.10.016.

22. Iacobucci TA, Daly BJ, Lindell D, Griffin MQ. Professional values, self-esteem, and ethical confidence of baccalaureate nursing students. Nurs Ethics. 2013;20(4):479-490. doi:10.1177/0969733012458608.

23. Kaya $H$, Işık $B$, Şenyuva $E$, Kaya N. Hemşirelik öğrencilerinin bireysel ve profesyonel değerleri. Anadolu Hemşirelik ve Sağlık Bilimleri Dergisi. 2012;15(1):18-26.

24. Alfred D, Yarbrough S, Martin P, Mink J, Lin YH, Wang LS. Comparison of professional values of Taiwanese and United States nursing students. Nurs Ethics. 2013;20(8):917-926. doi:10.1177/0969733013484486. 